\title{
Algorithms to estimate Antarctic sea ice algal biomass from under-ice irradiance spectra at regional scales
}

\author{
Jessica Melbourne-Thomas ${ }^{1,2, *}$, Klaus M. Meiners ${ }^{1,2}$, C. J. Mundy ${ }^{3}$, \\ Christina Schallenberg ${ }^{4}$, Katherine L. Tattersall ${ }^{5}$, Gerhard S. Dieckmann ${ }^{6}$
}

\footnotetext{
${ }^{1}$ Australian Antarctic Division, Department of the Environment, 203 Channel Highway, Kingston, Tasmania 7050, Australia

${ }^{2}$ Antarctic Climate \& Ecosystems Cooperative Research Centre, University of Tasmania, Hobart, Tasmania 7001, Australia

${ }^{3}$ Centre for Earth Observation Science, Clayton H. Riddell Faculty of Environment, Earth, and Resources, University of Manitoba, Winnipeg, Manitoba R3T 2N2, Canada

${ }^{4}$ School of Earth and Ocean Sciences, University of Victoria, Victoria, British Columbia V8P 5C2, Canada

${ }^{5}$ Integrated Marine Observing System, University of Tasmania, Hobart, Tasmania 7001, Australia

${ }^{6}$ Alfred Wegener Institute, Helmholtz Centre for Polar and Marine Research, 27570 Bremerhaven, Germany
}

\begin{abstract}
The presence of algal pigments in sea ice alters under-ice irradiance spectra, and the relationship between these variables can be used as a non-invasive means for estimating iceassociated algal biomass on ecologically relevant spatial and temporal scales. While the influence of snow cover and ice algal biomass on spectra transmitted through the snow-ice matrix has been examined for the Arctic, it has not been tested for Antarctic sea ice at regional scales. We used paired measurements of sea ice core chl a concentrations and hyperspectral-transmitted under-ice irradiances from 59 sites sampled off East Antarctica and in the Weddell Sea to develop algorithms for estimating algal biomass in Antarctic pack ice. We compared 4 approaches that have been used in various bio-optical studies for marine systems: normalised difference indices, ratios of spectral irradiance, scaled band area and empirical orthogonal functions. The percentage of variance explained by these models ranged from 38 to $79 \%$, with the best-performing approach being normalised difference indices. Given the low concentrations of integrated $\mathrm{chl}$ a observed in our study compared with previous studies, our statistical models performed surprisingly well in explaining variability in these concentrations. Our findings provide a basis for future work to develop methods for non-invasive time series measurements and medium- to large-scale spatial mapping of Antarctic ice algal biomass using instrumented underwater vehicles.
\end{abstract}

KEY WORDS: Sea ice algae $\cdot \mathrm{Chl} a \cdot$ Bio-optics $\cdot$ Normalised difference index $\cdot$ Weddell Sea $\cdot$ East Antarctica

Resale or republication not permitted without written consent of the publisher

\section{INTRODUCTION}

Ice algal communities in Antarctic sea ice form an important component of primary production in the Southern Ocean (Lizotte 2001, Arrigo et al. 2010); they support higher trophic levels and act as a food source for overwintering Antarctic krill larvae (Flores et al. 2012, Arrigo 2014). Primary productivity in sea ice is also critical in large-scale biogeochemical cycles that determine rates of carbon export and atmosphere-ocean exchange (Vancoppenolle et al. 2013). However, the high spatial variability of ice algal distribution prevents accurate in situ estimation of biomass at scales that are ecologically relevante.g. for regional-scale primary and secondary productivity - using classical sampling designs such as 
ice coring (Meiners et al. 2012). Recent circumpolar estimates of ice algal biomass for Antarctica are limited to records from historical ice core data that are unevenly distributed in space and time (Meiners et al. 2012) and model-based estimates that may underestimate internal communities (Saenz \& Arrigo 2014). Improved in situ data on temporal and spatial patterns of ice algal biomass distribution are needed for quantitative evaluation of sea ice primary production models and an improved understanding of the role of ice algae in Antarctic marine ecosystem function.

Antarctic pack ice provides a habitat for iceassociated algae, which form distinct surface, interior and bottom communities (Arrigo et al. 2010, Meiners et al. 2012). Surface communities are promoted by snow loading, surface flooding by seawater and brine, and subsequent snow-ice formation (Ackley et al. 2008). Interior communities can form either through the rafting and ridging of ice floes or by scavenging of phytoplankton during ice formation (i.e. the uptake of algal cells from the water column as ice crystals form; Arrigo et al. 2010). Bottom communities thrive in the lowermost porous parts of sea ice floes, where brine salinities and high nutrient availability favour algal growth (e.g. Vancoppenolle et al. 2010). The presence of photosynthetic pigments in these ice algal communities alters under-ice irradiance spectra through absorption at specific wavelengths of photosynthetically active radiation (Arrigo et al. 1993, Perovich et al. 1993, Mundy et al. 2007, Fritsen et al. 2011, Hawes et al. 2012). With increasing ice algal pigment concentration, transmitted under-ice irradiance spectra change from showing a broad peak centred at approximately $460 \mathrm{~nm}$ towards a narrow peak at wavelengths of approximately $570 \mathrm{~nm}$. Such a relationship - often measured as the ratio between intensities at key wavelengths - can potentially be used as an alternative non-invasive means for estimating ice-associated algal biomass (e.g. from transmitted spectra measured by instrumented underwater vehicles such as remotely operated vehicles and autonomous underwater vehicles). Several studies examining this relationship for ice algal communities have occurred in the Arctic (e.g. Legendre \& Gosselin 1991, Perovich et al. 1993, Mundy et al. 2007, McDonald et al. 2015) and a single study in the Antarctic (Fritsen et al. 2011); however, no study has yet tested the relationship across regional scales.

Transmitted and reflected spectra have been used in the Arctic and other marine environments to predict the concentration of photosynthetic pigments. Legendre \& Gosselin (1991) found that the under-ice transmitted irradiance ratio 671:540 nm explained approximately $50 \%$ of the observed integrated chl a concentration in Arctic fast ice. Perovich et al. (1993) demonstrated that the ratio of transmitted light at 600 and $450 \mathrm{~nm}$ can be used as an indicator of algal biomass in first-year Arctic sea ice. Mundy et al. (2007) employed normalised difference indices (NDIs) of under-ice irradiance spectra to investigate the influence of both ice algal biomass and snow on transmitted spectra under Arctic fast ice. The authors showed that snow has little effect on transmitted under-ice irradiances in the wavelength range of 400 to $570 \mathrm{~nm}$ and that ice algal biomass in Arctic fast ice explained $89 \%$ of the NDI wavelength combination 485:472 nm. Fritsen et al. (2011) used the NDI wavelength combination 555:442 $\mathrm{nm}$ to estimate temporal changes in integrated algal biomass at 3 sites in the Bellingshausen Sea (pack ice) during a time series experiment. This NDI wavelength pair explained $81 \%$ of the variation in integrated ice algal biomass.

Other bio-optical studies for open water systems have used simple ratios of spectral irradiance at particular wavelengths to estimate algal biomass. For example, Honda et al. (2009) found that the ratio of spectral irradiance at wavelengths of 555 and $443 \mathrm{~nm}$ at $40 \mathrm{~m}$ depth (the depth at which a moored radiometer was deployed) explained $80 \%$ of the variation in integrated chl $a$ in the surface water column in the Western Pacific Subarctic Gyre. Carrere et al. (2004) compared a series of methods for estimating the concentration of microphytobenthos chl a from sediment optical properties. These authors report that scaled band area, calculated by integrating the scaled absorption band depth over the wavelengths of particular absorption features, gave the best predictions of chl a $\left(\mathrm{R}^{2}=0.85\right)$ among the methods evaluated in their study. Finally, Craig et al. (2012) and Taylor et al. (2013) use empirical orthogonal function (EOF) analysis to reduce the dimensionality of hyperspectral data and relate independent modes of variability to phytoplankton pigment concentrations. These various approaches have never been directly compared, and it is unclear which might be most effective for predicting algal biomass in Antarctic sea ice.

The aim of our study was to compare existing biooptical approaches to predict chl a concentration in Antarctic pack ice using paired measurements of sea ice core chl a concentrations and hyperspectraltransmitted under-ice irradiances from 59 sites sampled off East Antarctica and in the Weddell Sea. Specifically, we compared algorithms based on 4 classes of methods (summarised in Table 1) that have been used for Arctic sea ice and other marine sys- 


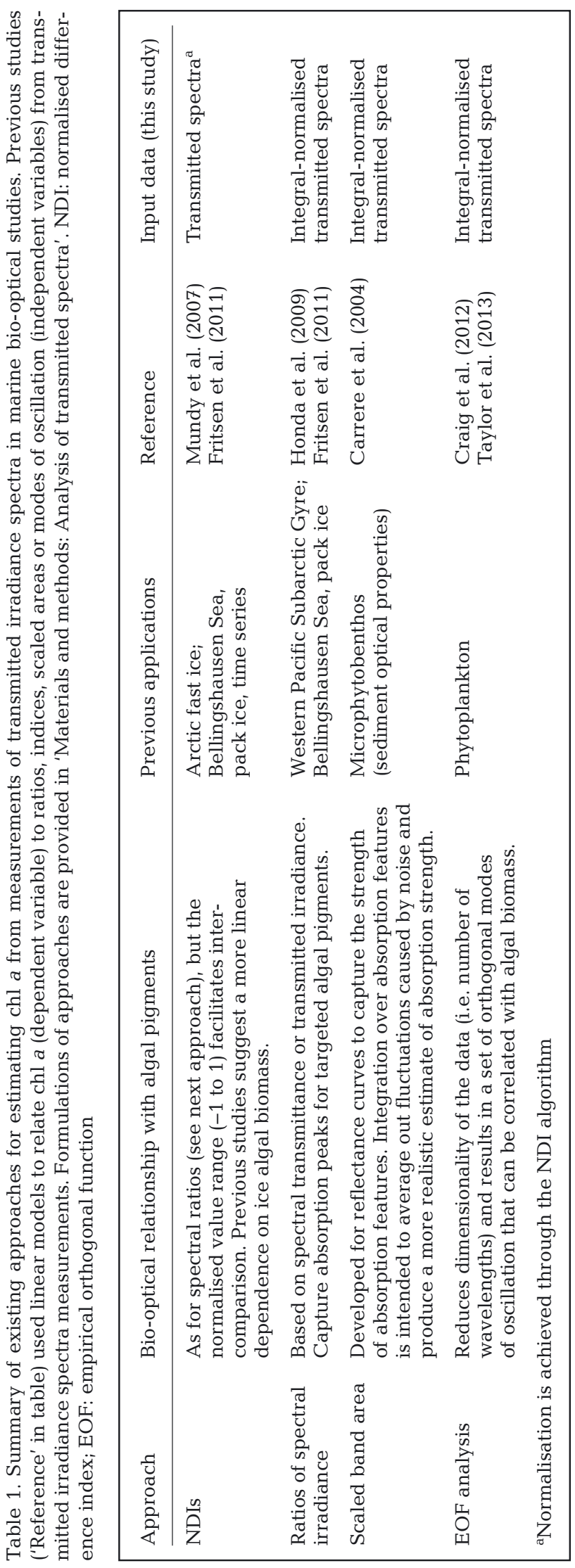

tems: NDIs, simple ratios of spectral irradiance, integrated features of transmitted irradiance spectra (scaled band areas) and EOF analysis. We directly compared the predictive capability of these approaches and examined their applicability between the 2 separate regions of Antarctica.

\section{MATERIALS AND METHODS}

\section{Study sites}

Paired under-ice irradiance measurements and ice core samples were collected during 3 expeditions (Fig. 1): the Winter Weddell Outflow Study (WWOS) voyage onboard the RV 'Polarstern' to the Weddell Sea in austral spring (September to October) 2006 (Lemke 2009) and 2 Sea Ice Physics and Ecosystems Experiment voyages (SIPEX1 and SIPEX2) onboard the RV 'Aurora Australis' to the 115 to $130^{\circ} \mathrm{E}$ sector off East Antarctica in austral spring (September to October) 2007 and 2012 (Worby et al. 2011). For the purposes of our analyses, i.e. our focus on developing and comparing algorithms between regions, data from the 2 SIPEX voyages in East Antarctic are combined. Exploratory analyses (model fitting) indicated that statistical models were more robust (less prone to overfitting) with the larger combined data set for East Antarctica.

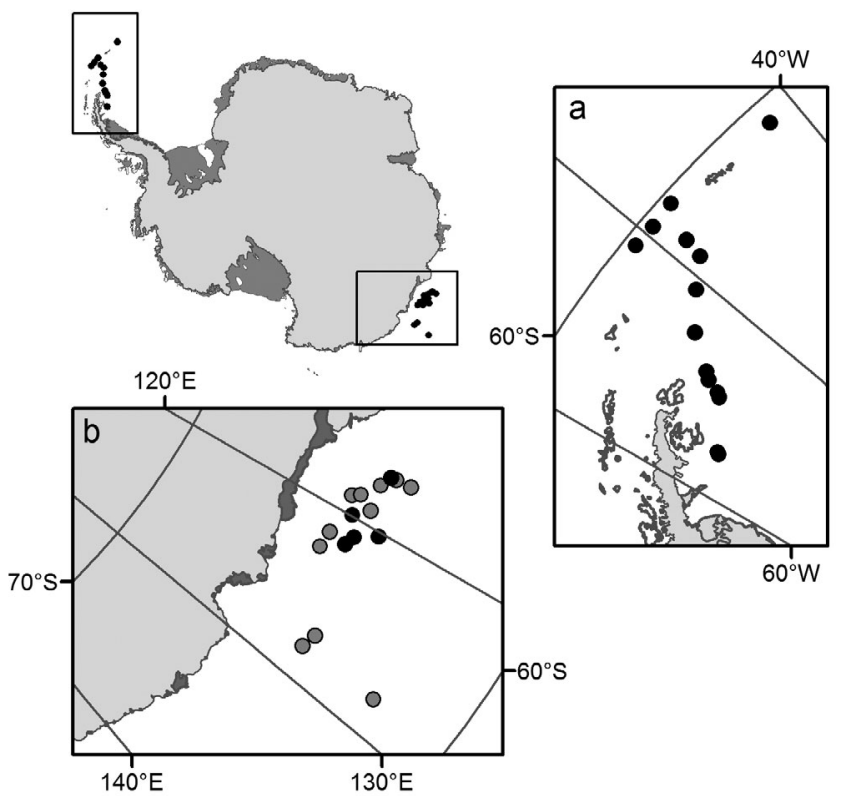

Fig. 1. Survey locations in (a) the Weddell Sea and (b) off East Antarctica. Station locations for the Winter Weddell Outflow Study (WWOS) voyage (2006) are shown in (a), and station locations for Sea Ice Physics and Ecosystems Experiments 1 (SIPEX1; 2007, o) and 2 (SIPEX2; 2012, •) are shown in (b) 
Antarctic sea ice extent is at its maximum in September (Parkinson \& Cavalieri 2012). Sea ice in the areas visited during the 3 voyages considered here was snow covered and was generally beginning to thin and loosen (break up) in the September to October period. Sampled ice floes on these voyages were several hundred meters to several kilometres in diameter and were all composite sea ice floes showing different degrees of deformation (ridging and rafting). Bio-optical sampling sites (1 to 5 sites per ice station, separated from each other by at least $20 \mathrm{~m}$ ) were chosen such that their immediate surroundings (20 m) showed no snow cover disturbances, were level and were free of surface deformations. All samples were taken during the middle of the day when the solar angle was high.

\section{Spectral measurements}

On each sampling site, we deployed a TriOS Ramses ACC VIS radiometer (cosine receptor, $180^{\circ}$ field of view) $0.15 \mathrm{~m}$ beneath the subsurface of the ice floe through an access hole (0.11 $\mathrm{m}$ diameter) using a retractable L-shaped stainless steel arm (Fig. 2). The hole effect on the light measurements was assumed to be negligible due to the position of the radiometer $0.9 \mathrm{~m}$ north (i.e. directed towards the sun) of the access hole. Under-ice high-resolution (400 to $700 \mathrm{~nm}$, $3.3 \mathrm{~nm}$ bandwidth) irradiance spectra were recorded with a laptop computer using TriOS MSDA software version 7.5.1. Results reported here represent average spectra calculated from a minimum of 10 replicate radiometer scans. Note that we measured transmitted irradiance spectra, not transmittance.

\section{Physical measurements and ice core processing}

At each site, snow depth was measured with a ruler (5 replicate measurements) and an ice core was collected, using a manual Kovacs Mark II ice core system (0.09 $\mathrm{m}$ internal diameter), directly above the radiometer location. Medium-scale spatial variability was addressed by sampling from multiple sites at each ice station.

The length of the collected ice core was recorded, and the entire core was divided into sections (one $10 \mathrm{~cm}$ bottom section and 3 equal-length sections) and then placed in clean polyethylene containers and transported back to the ship's laboratories. On the ship, ice core sections were melted at $4{ }^{\circ} \mathrm{C}$ in the dark within 12 to $36 \mathrm{~h}$ of collection. After the ice cores

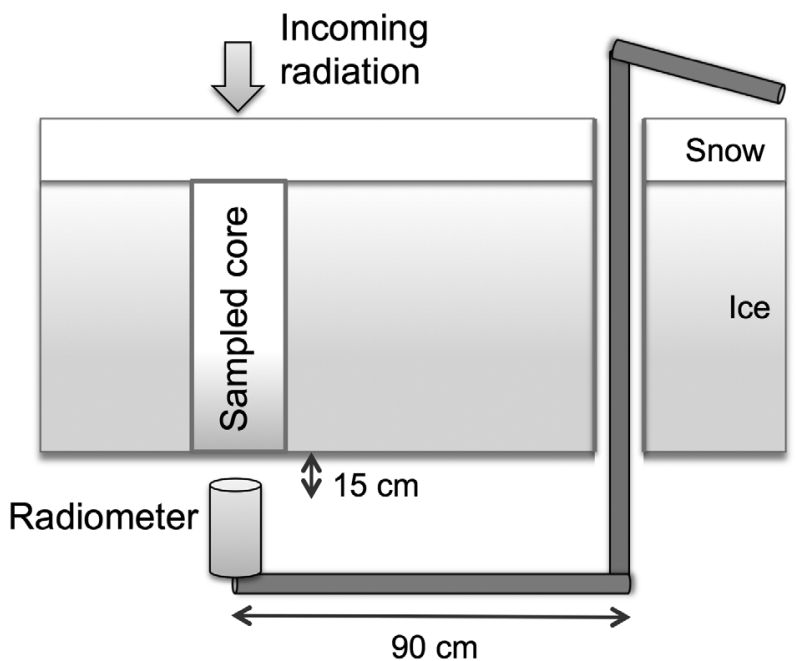

Fig. 2. Sampling design for spectral measurements used on voyages in the Weddell Sea and East Antarctica

had melted, samples were gently mixed, and subsamples were filtered onto Whatman GF/F glass fibre filters, extracted with $90 \%$ acetone (WWOS) or methanol (SIPEX voyages) and analysed for chl a with a Turner Designs 10AU fluorometer according to standard protocols (Holm-Hansen et al. 1965, Arar $\&$ Collins 1997). Ice core section data (chl a in $\mu \mathrm{g} \mathrm{l}^{-1}$ ) were integrated over the entire ice thickness and are expressed as integrated $\mathrm{chl} \mathrm{a}\left(\mathrm{mg} \mathrm{m}^{-2}\right)$.

\section{Analysis of transmitted spectra}

All transmitted spectra were interpolated to consecutive integer $(1 \mathrm{~nm})$ wavelengths in the range of 400 to $700 \mathrm{~nm}$. Ratios, scaled band areas and EOFs were calculated using integral-normalised transmitted irradiance (i.e. normalised $E_{\mathrm{d}}$ over the 400 to $700 \mathrm{~nm}$ range) to minimise the amplitude component of spectral variability and to focus on differences in spectral shape. We considered the relationship between snow depth and transmitted irradiance using NDIs but not ratios, scaled band area or EOFs. Mundy et al. (2007) showed that for the Arctic, snow has a minor influence on the spectral distribution of transmitted under-ice irradiances in the wavelength range of 400 to $570 \mathrm{~nm}$. The calculations of ratios and scaled band area described below are therefore unlikely to be influenced by snow depth. Furthermore, because EOFs partition variability in spectra due to different signals, this approach should be capable of partitioning variability due to snow depth as compared with algal biomass (provided that algal biomass is not correlated with snow depth; see 'Algorithms', below). 


\section{NDIs}

Following Mundy et al. (2007), we calculated NDIs for all possible wavelength combinations of measured transmitted irradiances ( $T \lambda, 400$ to $700 \mathrm{~nm}$ ) according to:

$$
\mathrm{NDI}=\left[\left(T \lambda_{1}\right)-\left(T \lambda_{2}\right)\right] /\left[\left(T \lambda_{1}\right)+\left(T \lambda_{2}\right)\right]
$$

The NDIs for each wavelength pair were then correlated with integrated chl $a$ and snow depth, and the resultant Pearson correlation coefficients were placed in 2 separate matrices with $\lambda_{1}$ and $\lambda_{2}$ as their axes. NDI wavelength pairs that gave the best correlation with each variable were determined by selecting a threshold between 0.7 and 0.9 that resulted in a single region of correlations higher than the threshold, recording the coordinates of this region and then taking the mid-point.

\section{Ratios}

We adopted the wavelength ratio used by Honda et al. (2009) of $E_{\mathrm{d}}(555) / E_{\mathrm{d}}(443)$, noting that this is consistent with the ratio considered by Fritsen et al. (2011; for the Bellingshausen Sea, Antarctica) of $E_{\mathrm{d}}(555) / E_{\mathrm{d}}(442)$.

\section{Scaled band area}

Carrere et al. (2004) determined the scaled area of absorption features using reflectance spectra from

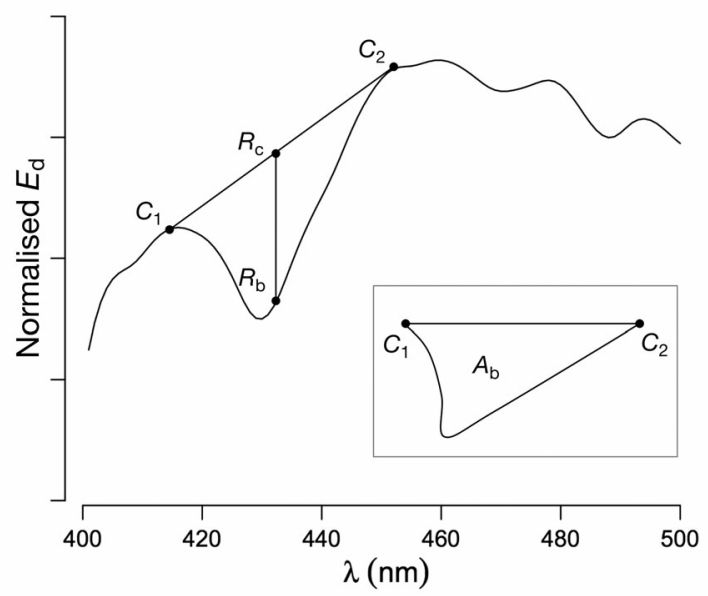

Fig. 3. Calculation of scaled band area ( $A_{\mathrm{b}}$ Eq. 2) based on normalised spectra for transmitted irradiance. $C_{1}$ and $C_{2}$ are the wavelengths at which there is maximum transmitted irradiance between 400-430 and 430-450 nm, respectively; $R_{\mathrm{C}}$ is the straight line of irradiance connecting $C_{1}$ and $C_{2 i}$ and $R_{\mathrm{b}}$ is the normalised spectral irradiance. $E_{\mathrm{d}}$ : transmitted irradiance; $\lambda$ : wavelength sediment surfaces in the intertidal zone in the English Channel. Scaled band area is a dimensionless quantity and is calculated by integrating the scaled band depth over the wavelengths of a spectral feature (Fig. 3). We adapted this method to under-ice irradiance spectra and calculated scaled band area, $A_{\mathrm{b}}$, of the consistent feature of these irradiance spectra between 400 and $450 \mathrm{~nm}$ (the interval within which the maximum of chl a specific absorption occurs) as:

$$
A_{b}=\int_{C_{1}}^{C_{2}} \frac{\left(R_{\mathrm{c}}-R_{\mathrm{b}}\right)}{R_{\mathrm{c}}}
$$

where $C_{1}$ and $C_{2}$ are the wavelengths at which there is maximum transmitted irradiance between $400-430$ and $430-450 \mathrm{~nm}$, respectively; $R_{\mathrm{c}}$ is the straight line of irradiance connecting $C_{1}$ and $C_{2} ;$ and $R_{\mathrm{b}}$ is the normalised spectral irradiance.

\section{EOFs}

EOF analysis of spectral data has the advantage of reducing the high dimensionality of spectral data and deriving the dominant signals (modes) that best describe variance within the observed spectra. As shown by Craig et al. (2012) and Taylor et al. (2013), EOFs can be represented graphically as independent modes of oscillation in spectral shape.

EOF analysis was conducted using an $M \times N$ matrix of integral-normalised transmitted irradiance at each wavelength $(M)$ for all observations (samples, $N)$. The corresponding covariance matrix was then subjected to an eigen decomposition to obtain eigenvectors (the EOFs) and eigenvalues. The eigenvectors are represented as an $N \times N$ matrix containing scores for each sample by mode. EOF expansion coefficients (i.e. principal components) are represented as an $M \times N$ matrix carrying the loadings for each wavelength by mode. We selected the first 4 EOFs for further analysis.

\section{Algorithms}

We used linear models to explore the relationship between integrated chl a from ice cores and predictive variables from each method described above (noting that linear models have been used in previous studies estimating chl a from bio-optical data). Only cores with ice thickness less than $1.5 \mathrm{~m}$ were considered in our analyses (i.e. undeformed first-year ice; Heil et al. 1996, Worby \& Allison 1999). All reported $\mathrm{R}^{2}$ values are adjusted $\mathrm{R}^{2}$ to allow comparison 
Table 2. Summary statistics for physical sea ice parameters and integrated chl a concentrations in sea ice sampled during 3 voyages (where $\mathrm{n}$ is the number of sampling sites). Reported values are mean \pm standard error. Only cores with ice thickness less than $1.5 \mathrm{~m}$ were considered in our analyses (i.e. undeformed first-year pack ice; Heil et al. 1996, Worby \& Allison 1999). WWOS: Winter Weddell Outflow Study; SIPEX1, SIPEX2: Sea Ice Physics and Ecosystems Experiments 1 (2007) and 2 (2012)

\begin{tabular}{|lccc|}
\hline Parameter & $\begin{array}{c}\text { WWOS } \\
(\mathrm{n}=19)\end{array}$ & $\begin{array}{c}\text { SIPEX1 } \\
(\mathrm{n}=26)\end{array}$ & $\begin{array}{c}\text { SIPEX2 } \\
(\mathrm{n}=14)\end{array}$ \\
\hline Ice thickness $(\mathrm{m})$ & $1.18 \pm 0.05$ & $0.63 \pm 0.06$ & $1.07 \pm 0.06$ \\
Snow depth $(\mathrm{m})$ & $0.15 \pm 0.04$ & $0.09 \pm 0.02$ & $0.20 \pm 0.04$ \\
Chl $a\left(\mathrm{mg} \mathrm{m}^{-2}\right)$ & $6.69 \pm 1.29$ & $0.86 \pm 0.19$ & $0.82 \pm 0.18$ \\
\hline
\end{tabular}

between models with different numbers of predictors. Given multiple predictors for the EOF approach, we used multiple linear regression with backwards elimination based on Akaike's Information Criterion to select the final models (Burnham \& Anderson 2002). To test the applicability of NDI ratios between regions (East Antarctica and the Weddell Sea), we also fitted a relationship for the smaller data set (WWOS) based on the NDI determined for the large data set (SIPEX). All analyses were conducted using the statistical computing software R (R Core Team 2015).

\section{RESULTS}

Summary statistics for snow and ice thickness as well as integrated chl $a$ are provided in Table 2. Integrated chl a concentrations from all 3 expeditions were significantly correlated with ice thickness but showed no correlation with snow depth (Fig. 4; note that integrated chl $a$ is presented on a log scale in this figure). Mean integral-normalised transmitted under-ice irradiance spectra for the 3 expeditions and for low (0 to $1 \mathrm{mg} \mathrm{m}^{-2}$ ) and high (1 to $20 \mathrm{mg} \mathrm{m}^{-2}$ ) integrated $\mathrm{chl}$ a concentrations are presented in Fig. 5. Correlation surfaces of NDIs for integrated chl a showed a pronounced switch from negative to positive correlations at $440 \mathrm{~nm}$ for both East Antarctica and the Weddell Sea (Fig. 6a,c), consistent with results from Mundy et al. (2007) for the Arctic and with maxima of particulate, ice algal and chl a specific absorption (SooHoo et al. 1987, Bricaud et al. 2004, van Leeuwe et al. 2005).

The performances of our 4 alternative approaches are summarised by region in Table 3. All models required log transformation of integrated chl $a$ to adjust
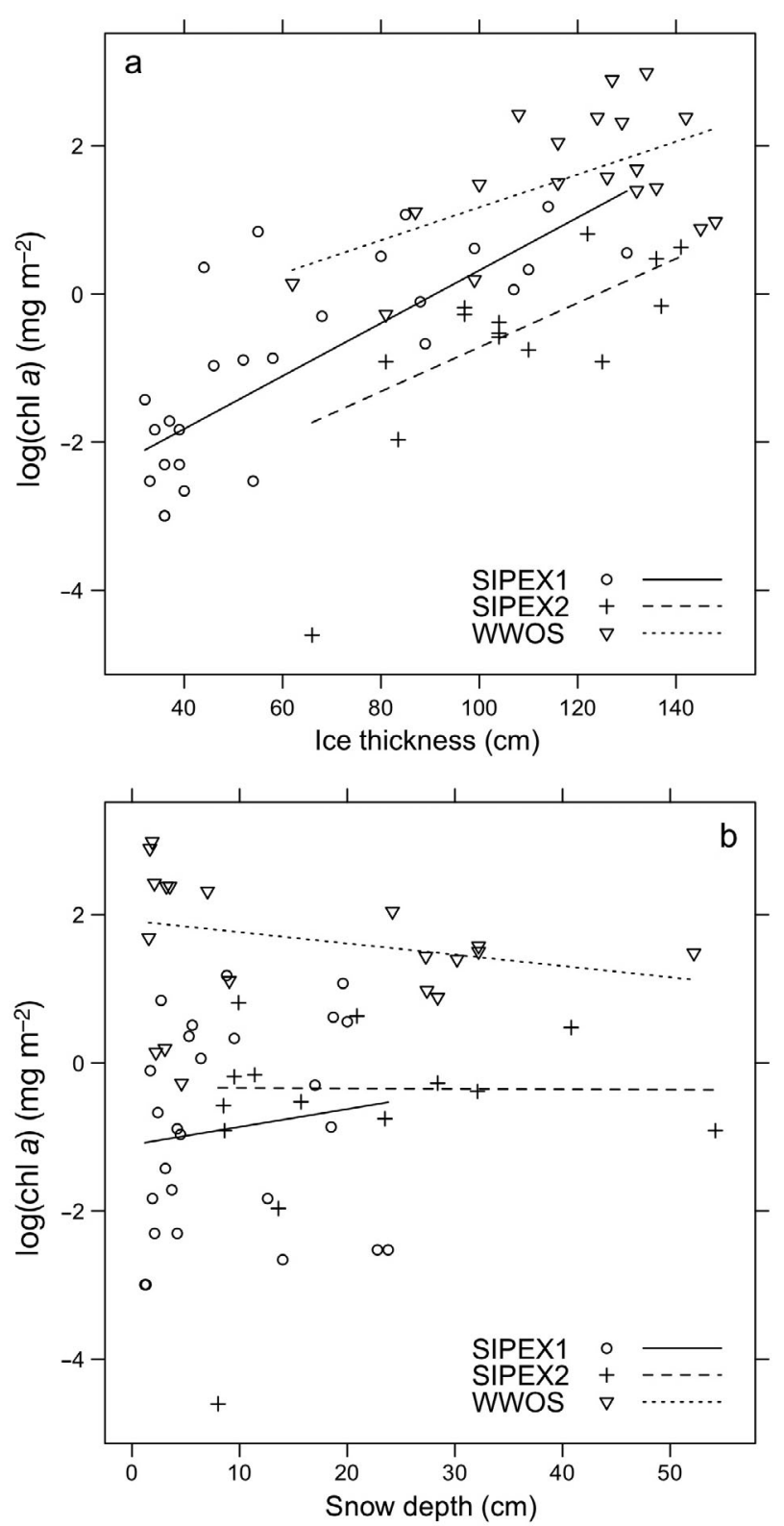

Fig. 4. Relationship between integrated chl $a$ and (a) ice thickness and (b) mean snow depth. Two-way ANCOVAs indicate homogeneity of slopes and significant differences in intercepts between voyages for both ice thickness $\left(F_{2,55}=\right.$ $19.0, \mathrm{p}<0.0001)$ and snow depth $\left(F_{2,55}=23.1, \mathrm{p}<0.0001\right)$. There is also a significant effect of ice thickness on chl a $\left(F_{2,55}=57.0, \mathrm{p}<0.0001\right)$ but no effect of snow depth on chl a $\left(F_{1,55}=0.19, \mathrm{p}<0.68\right)$. SIPEX1, SIPEX2: Sea Ice Physics and Ecosystems Experiments 1 (2007) and 2 (2012); WWOS: Winter Weddell Outflow Study

for heteroscedasticity (i.e. higher variance for higher values) and were significant, with the proportion of variance explained higher than $50 \%$. NDIs had the highest predictive power, and the highest correlations with integrated chl a were found for wavelength pairs of 422:418 nm (East Antarctica) and 

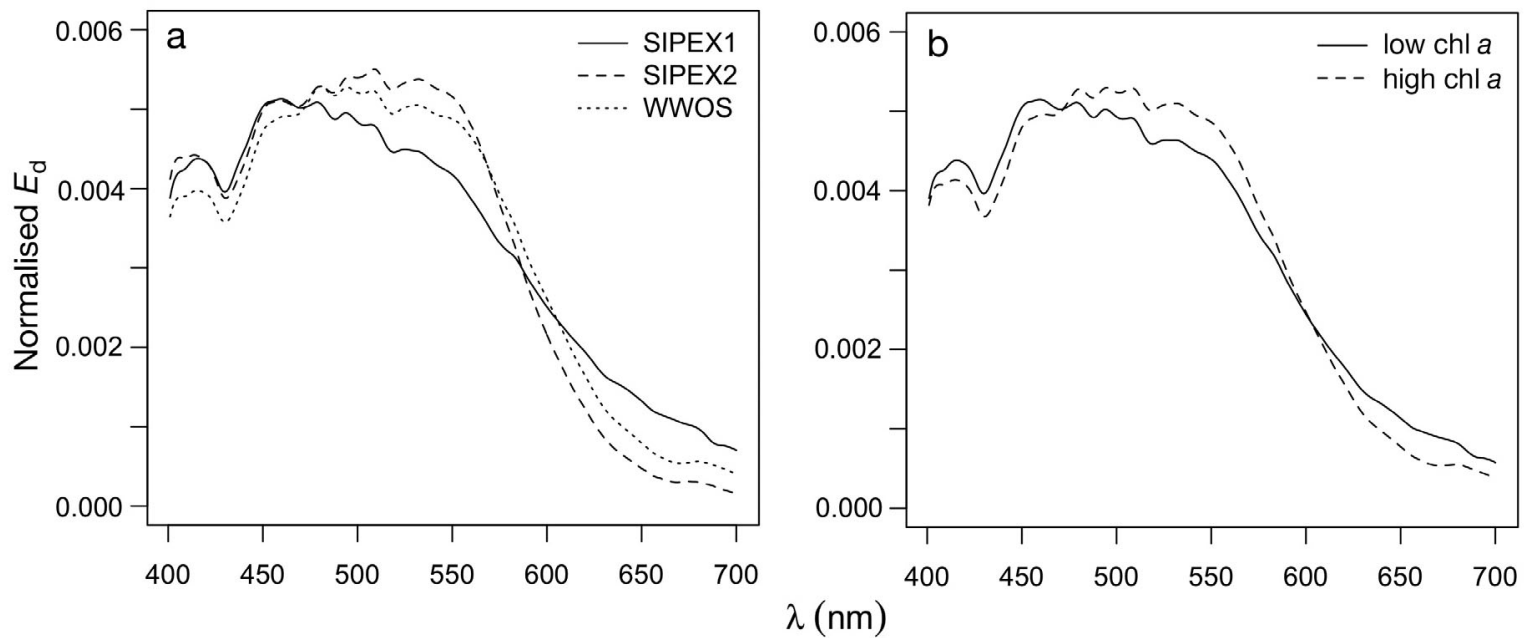

Fig. 5. Mean transmitted under-ice irradiance spectra (normalised to area under curve) for (a) Sea Ice Physics and Ecosystems Experiments 1 (SIPEX1, 2007) and 2 (SIPEX2, 2012) and Winter Weddell Outflow Study (WWOS) and (b) low (0 to $1 \mathrm{mg}^{-2}$ ) and high (1 to $\left.20 \mathrm{mg} \mathrm{m}^{-2}\right)$ integrated $\mathrm{chl} a$. $E_{\mathrm{d}}$ : transmitted irradiance; $\lambda$ : wavelength

a) SIPEX: Chl a

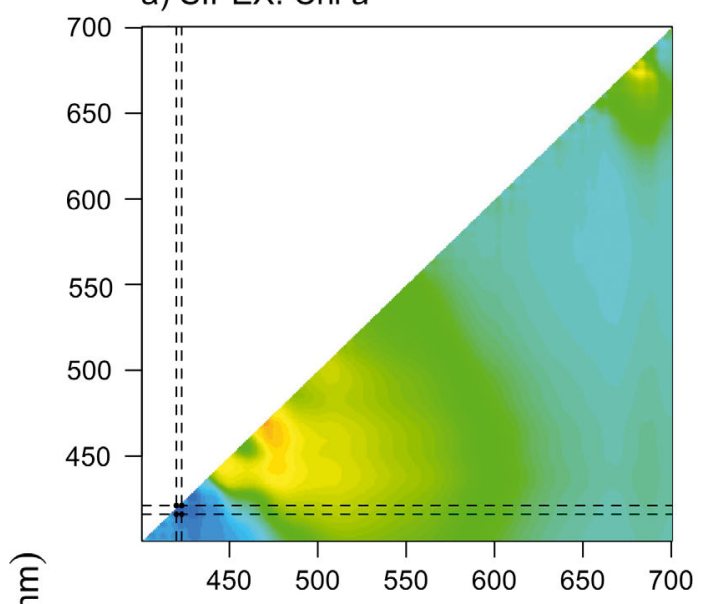

c) WWOS: $\mathrm{Chl}$ a

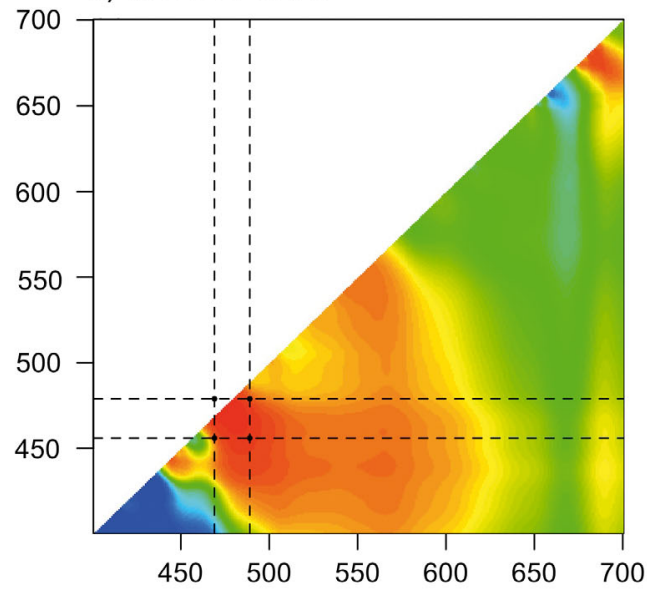

b) SIPEX: Snow

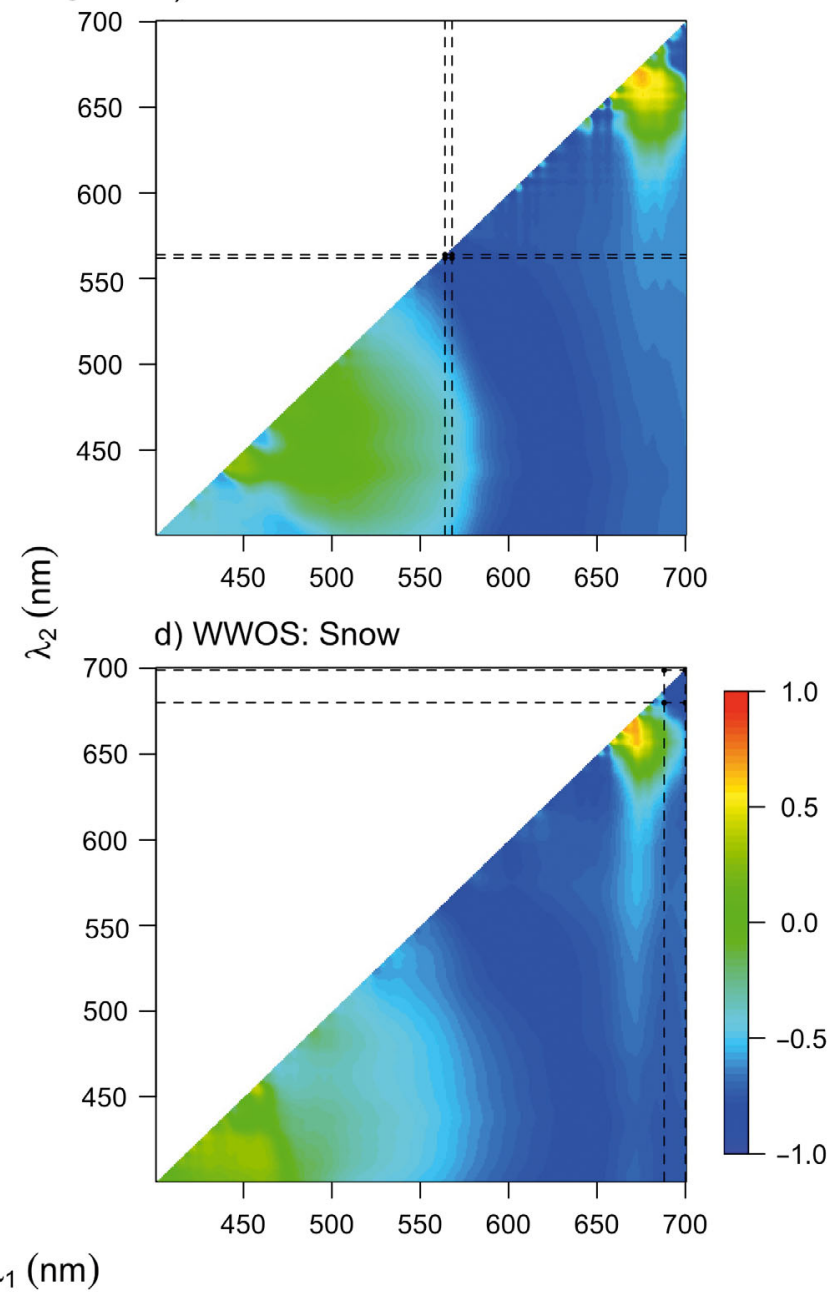

Fig. 6. Correlation surfaces of normalised difference indices for $(a, c)$ integrated chl $a$ and $(b, d)$ snow depth for the $(a, b)$ Sea Ice Physics and Ecosystems Experiments (SIPEX1 and SIPEX2, East Antarctica) and (c,d) Winter Weddell Outflow Study (WWOS, Weddell Sea) data. Dashed lines identify regions of these surfaces with the highest absolute correlation values. $\lambda_{1}, \lambda_{2}$ : wavelength pairs (see Eq. 1) 
Table 3. Comparison of algorithms for estimating integrated chl a. For the empirical orthogonal function (EOF) methods, S1 to S4 are the scores of the first 4 EOFs. SIPEX1, SIPEX2: Sea Ice Physics and Ecosystems Experiments 1 (2007) and 2 (2012); NDI: normalised difference index; $E_{\mathrm{d}}$ : transmitted irradiance; sba: scaled band area; WWOS: Winter Weddell Outflow Study

\begin{tabular}{|c|c|c|c|c|}
\hline Region & Method & Observed relationship & $\mathrm{R}^{2}$ & $\mathrm{p}$ \\
\hline $\begin{array}{l}\text { East Antarctica } \\
\text { (SIPEX1, SIPEX2) }\end{array}$ & $\begin{array}{l}\text { NDI } \\
E_{\mathrm{d}}(555) / E_{\mathrm{d}}(443) \\
\text { Scaled band area } \\
\text { EOFs }\end{array}$ & $\begin{array}{l}\ln (\operatorname{chl} a)=-4.27-351 \times \mathrm{NDI}(422: 418) \\
\ln (\operatorname{chl} a)=-1103+1948 \times E_{\mathrm{d}}(555) / E_{\mathrm{d}}(443)-859 \times\left[E_{\mathrm{d}}(555) / E_{\mathrm{d}}(443)\right]^{2} \\
\ln (\mathrm{chl} a)=-16.36+9.52 \times \mathrm{sba}-1.34 \times \mathrm{sba}^{2} \\
\ln (\mathrm{chl} a)=0.36+6.41 \times \mathrm{S} 1-143.5 \times \mathrm{S} 2-20970 \times \mathrm{S}^{2}+393.3 \times \mathrm{S} 3-512.6 \times \mathrm{S} 4\end{array}$ & $\begin{array}{l}0.64 \\
0.56 \\
0.64 \\
0.52\end{array}$ & $\begin{array}{l}<0.0001 \\
<0.0001 \\
<0.0001 \\
<0.0001\end{array}$ \\
\hline $\begin{array}{l}\text { Weddell Sea } \\
\text { (WWOS) }\end{array}$ & $\begin{array}{l}\text { NDI } \\
E_{\mathrm{d}}(555) / E_{\mathrm{d}}(443) \\
\text { Scaled band area } \\
\text { EOFs }\end{array}$ & $\begin{array}{l}\ln (\operatorname{chl} a)=-0.39-31.7 \times \mathrm{NDI}(479: 468) \\
\ln (\operatorname{chl} a)=-33.9+31.0 \times E_{\mathrm{d}}(555) / E_{\mathrm{d}}(443) \\
\ln (\mathrm{chl} a)=-2.40+1.64 \times \mathrm{sba}-0.13 \times \mathrm{sba}^{2} \\
\ln (\operatorname{chl} a)=1.55+43.0 \times \mathrm{S} 1+112.5 \times \mathrm{S} 2-243.7 \times \mathrm{S} 3\end{array}$ & $\begin{array}{l}0.79 \\
0.67 \\
0.60 \\
0.67\end{array}$ & $\begin{array}{r}<0.0001 \\
0.0001 \\
0.0003 \\
0.0001\end{array}$ \\
\hline
\end{tabular}

a) SIPEX: Chl a

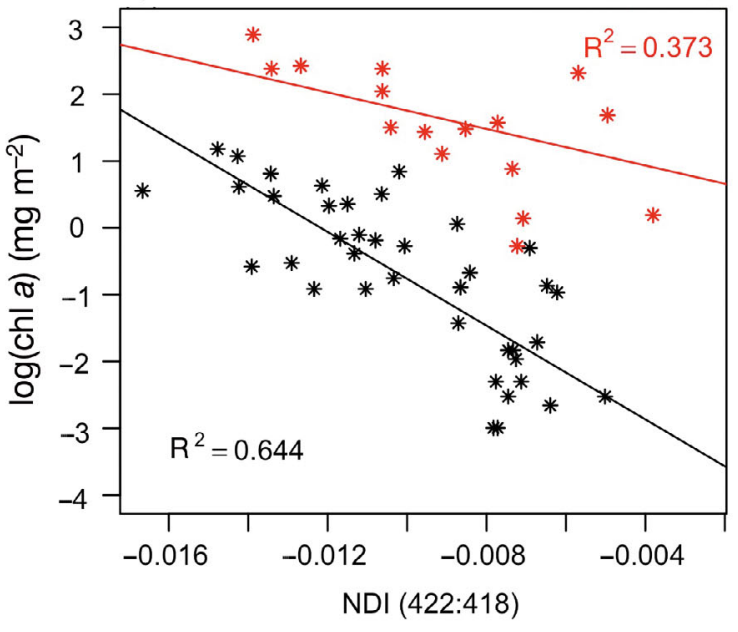

c) WWOS: Chl a

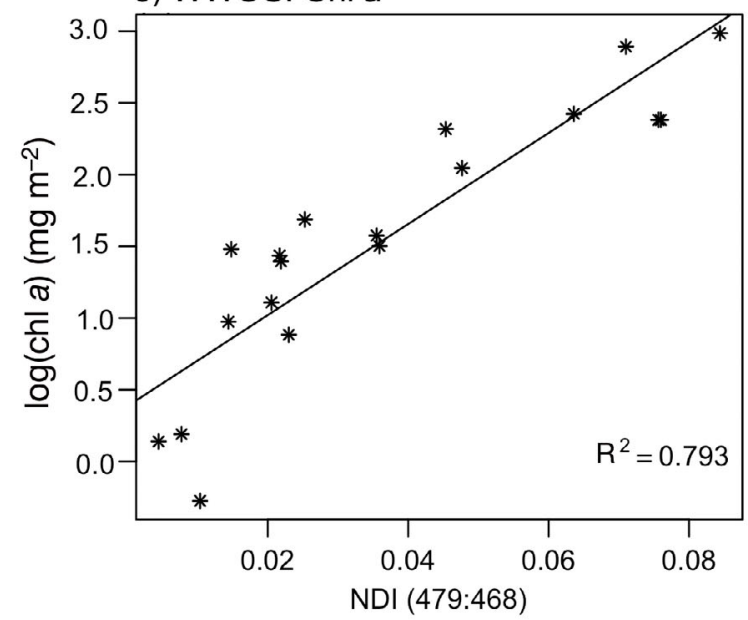

b) SIPEX: Snow

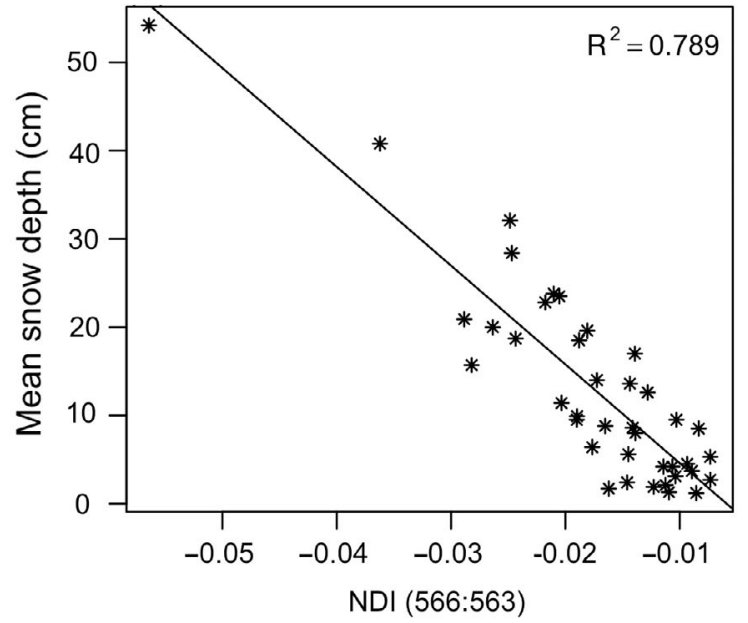

d) WWOS: Snow

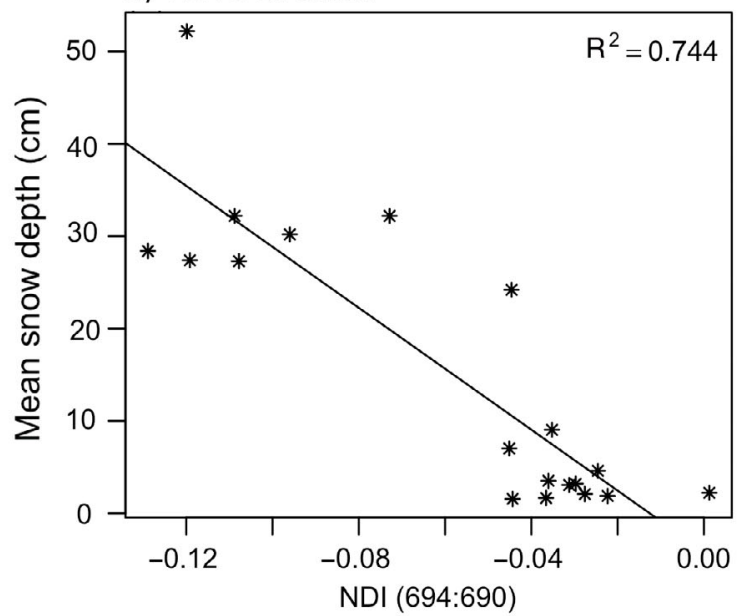

Fig. 7. Relationships between observed normalised difference indices (NDIs) and $(\mathrm{a}, \mathrm{c})$ integrated chl $a$ and (b,d) mean snow depth for the $(\mathrm{a}, \mathrm{b})$ Sea Ice Physics and Ecosystems Experiments (SIPEX1 and SIPEX2, East Antarctic) and (c,d) Winter Weddell Outflow Study (WWOS, Weddell Sea). Wavelength pairs (nm) determined from examination of correlation surfaces (Fig. 6) are indicated in $x$-axis labels. Equations and significance of fitted relationships are provided in Table 3. The fitted relationship for WWOS integrated chl a based on the NDI $(422: 418 \mathrm{~nm})$ derived from SIPEX is shown in red in (a), $p=0.003$ 

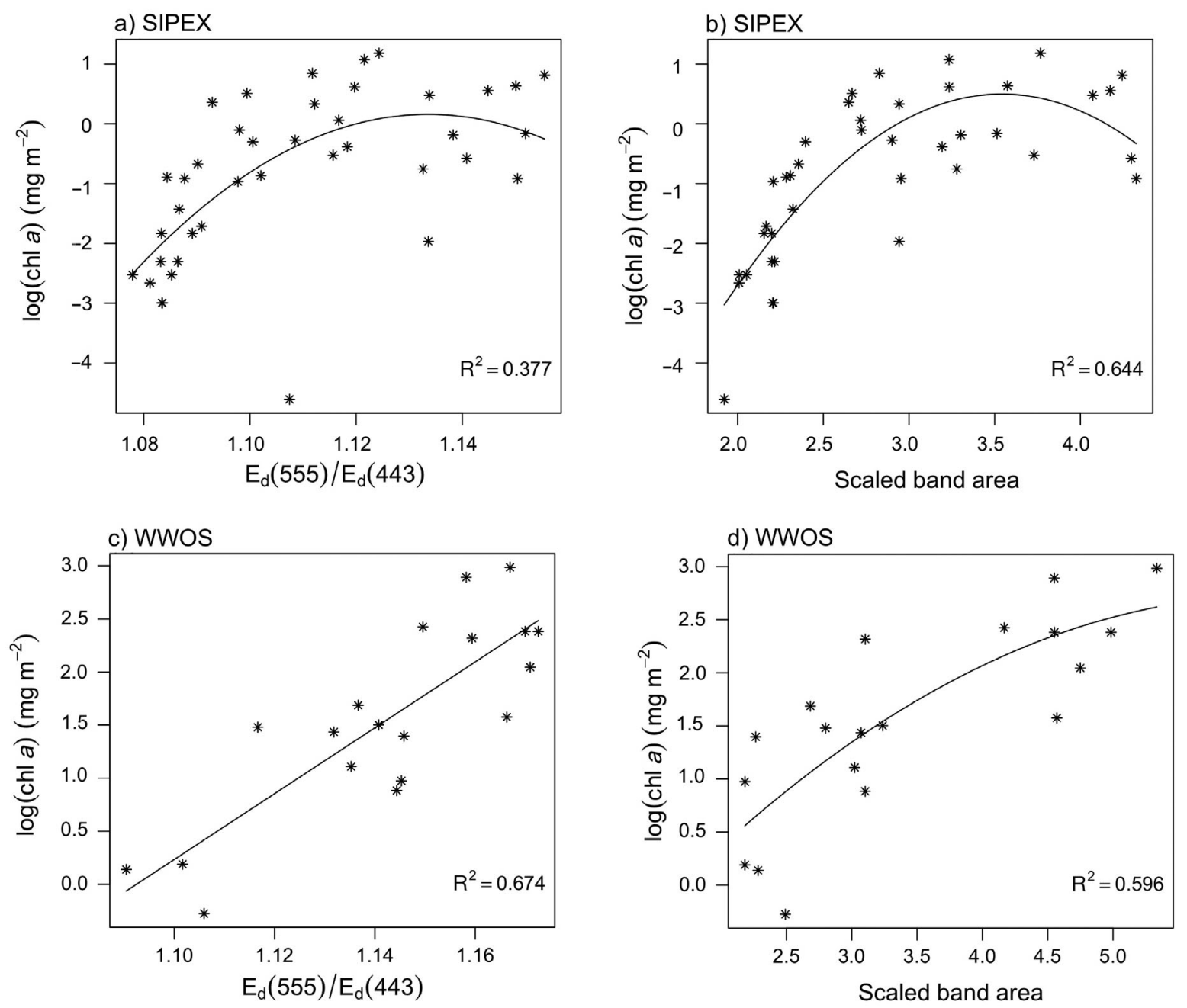

Fig. 8. Relationships between observed integrated chl $a$ and $(\mathrm{a}, \mathrm{c})$ transmitted irradiance ratio $E_{\mathrm{d}}(555) / E_{\mathrm{d}}(443)$ and $(\mathrm{b}, \mathrm{d}) \mathrm{scaled}$ band area for the $(\mathrm{a}, \mathrm{b})$ Sea Ice Physics and Ecosystems Experiments (SIPEX1 and SIPEX2, East Antarctic) and (c,d) Winter Weddell Outflow Study (WWOS, Weddell Sea). The removal of a single outlier in (a) gave an $\mathrm{R}^{2}$ value of 0.56 as reported in Table 3. All equations and significance of fitted relationships are provided in Table 3

479:468 $\mathrm{nm}$ (Weddell Sea). Wavelength pairs that gave high correlations with snow depth $(566: 563 \mathrm{~nm}$, $\mathrm{R}^{2}=0.79$ for East Antarctica and $694: 690 \mathrm{~nm}, \mathrm{R}^{2}=$ 0.74 for the Weddell Sea; see Fig. 7) were non-overlapping with NDI wavelengths for chl $a$. We note that single outlying points in SIPEX NDI regressions for chl a (Fig. 7a) and snow (Fig. 7b) are 2 different sampling sites. Removal of these sites from respective analyses still produced significant regressions with similar $\mathrm{R}^{2}$ values. The model for WWOS integrated chl a based on the NDI ratio (422:418 nm) determined from SIPEX explained $37 \%$ of the variability in observed chl a for the Weddell Sea. The fitted relationship is shown in red in Fig. 7a.

Models relating chl $a$ to scaled band area required linear and quadratic terms for both regions (Table 3 ,
Fig. 8) and explained on the order of $60 \%$ of the variation in chl $a$. The $E_{\mathrm{d}}(555) / E_{\mathrm{d}}(443)$ model for East Antarctica also required a quadratic term and explained $38 \%$ of the variation in chl a $(56 \%$ when a single outlier with low chl a was removed). The worst-performing algorithm by region combination was the EOF analysis for East Antarctica. EOF analysis and model fitting for the 2 separate voyages in East Antarctica gave significant fits, with $\mathrm{R}^{2}$ values of 0.86 and 0.82 for SIPEX1 and SIPEX2, respectively. However, these models had very different formulations, with Modes 1 to 4 as predictors for SIPEX1 and only the second and fourth modes as predictors for SIPEX2.

The modes of oscillation in EOF loadings (Figs. 9 \& 10) can be interpreted as signatures of changes in 

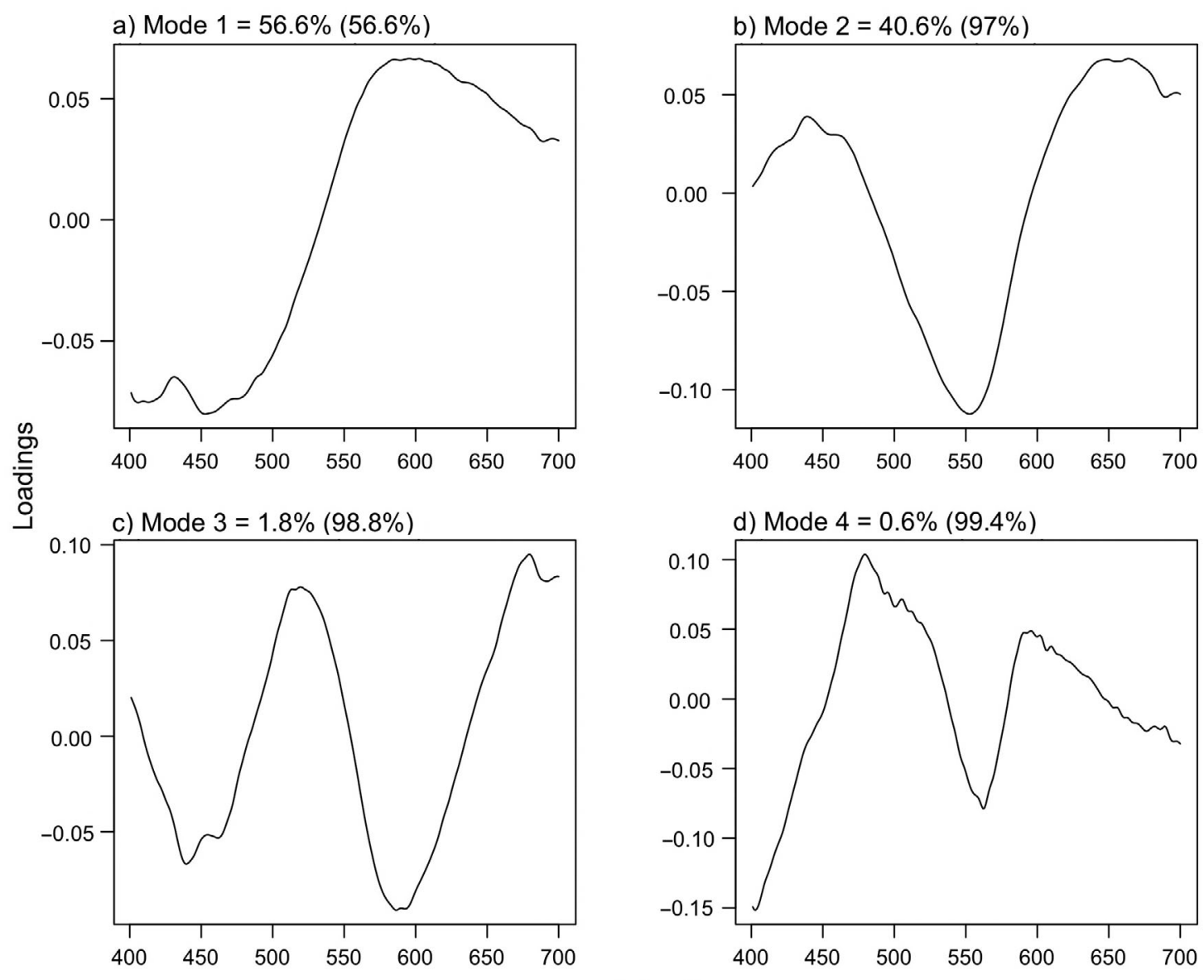

d) Mode $4=0.6 \%(99.4 \%)$

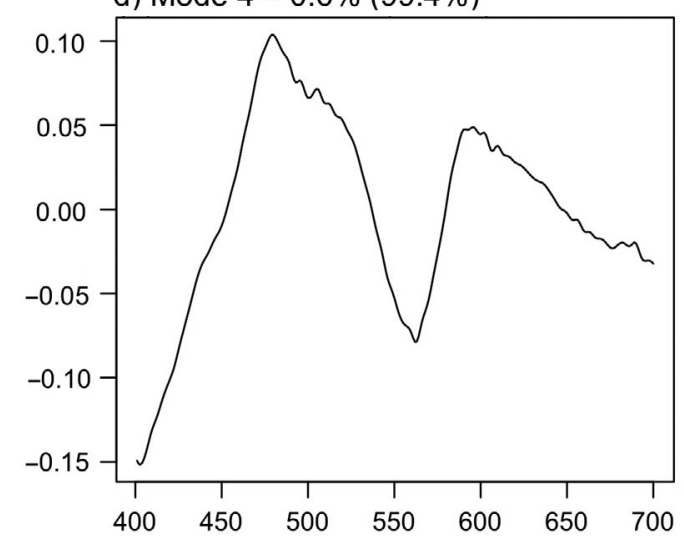

$\lambda(\mathrm{nm})$

Fig. 9. Loadings, percent variance and cumulative proportion of variance represented (in parentheses) for Modes 1 to 4 of empirical orthogonal function analysis of transmitted spectra for the Sea Ice Physics and Ecosystems Experiments (SIPEX1 and SIPEX2, East Antarctica). $\lambda$ : wavelength

the optical properties of absorbing constituents (as demonstrated by Craig et al. 2012 and Taylor et al. 2013). For the Weddell Sea, Mode 1 includes the chl a fluorescence emission peak at $\sim 683 \mathrm{~nm}$ noted by Craig et al. (2012) as a signature of changes in chl a (Fig. 10a). Mode 2 for this region (Fig. 10b) resembles Mode 1 but with a change in the sign of the loading at around $600 \mathrm{~nm}$, which may be associated with differences in the degree of scattering by snow. Spectral inflections in Modes 3 and 4 may be attributable to variability in phytoplankton pigment composition, although these modes capture very small proportions of the total variability in spectral shape $(0.7$ and $0.6 \%$ ), and only Modes 1 to 3 were included in the fitted multiple regression model for chl a (Table 3). For East Antarctica, Modes 2 and 4 were similar in shape (Fig. 9b,d) and exhibited relatively strong negative loadings at $\sim 550 \mathrm{~nm}$. As for the Weddell Sea, inflections in Mode 3 for this region (Fig. 10c) may be associated with variable pigment compositions. All 4 modes were included in the final fitted model for East Antarctica (Table 3).

\section{DISCUSSION}

Given the importance of sea ice habitats in Antarctic marine ecosystems (Arrigo 2014) and the potential but currently uncertain contribution of ice algae to overall Southern Ocean primary productivity (Lizotte 2001, Saenz \& Arrigo 2014), there is a strong need for improved estimates of ice algal biomass distribution at meso- to regional scales. In this study, we evaluated alternative approaches to estimating chl a from bio-optical measurements under Antarctic sea ice in 2 regions: the Weddell Sea and East Antarctica. Our results indicate that NDIs provide the most robust predictions of integrated chl $a$, both at the regional scale and as a general method that is applicable across multiple regions. 
a) Mode $1=82.5 \%(82.5 \%)$

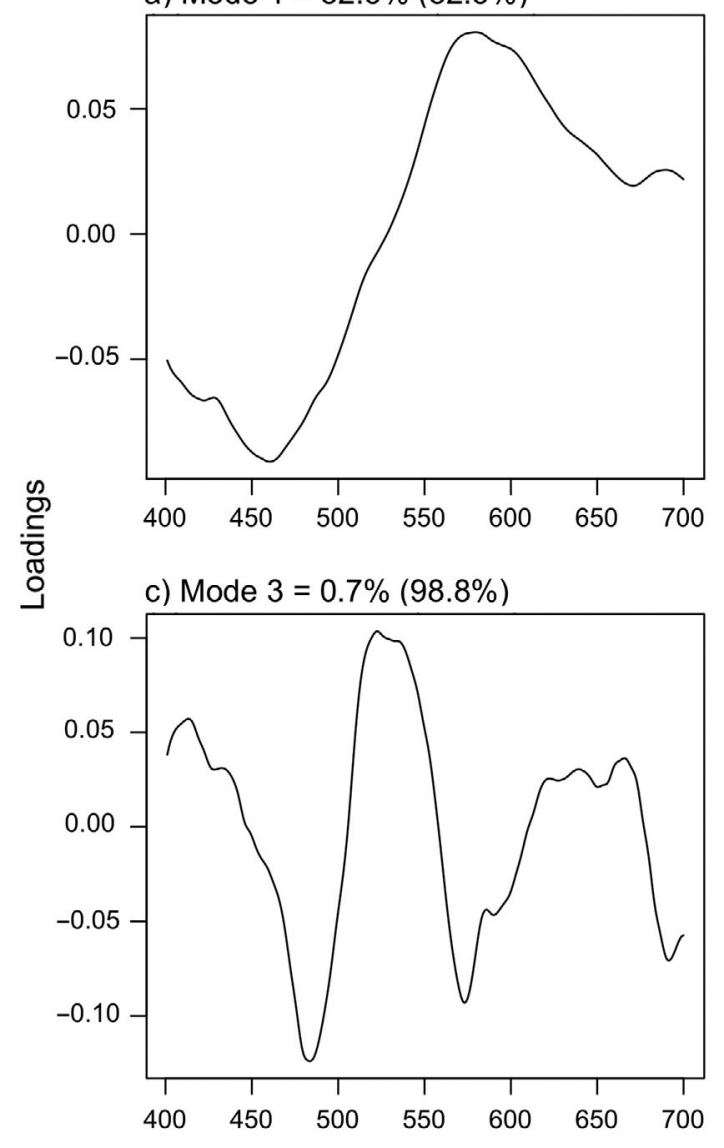

b) Mode $2=15.6 \%(98.1 \%)$

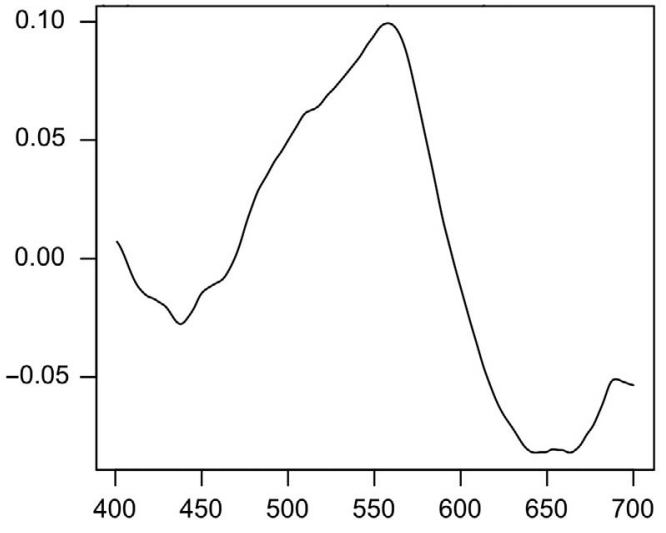

d) Mode $4=0.6 \%(99.4 \%)$

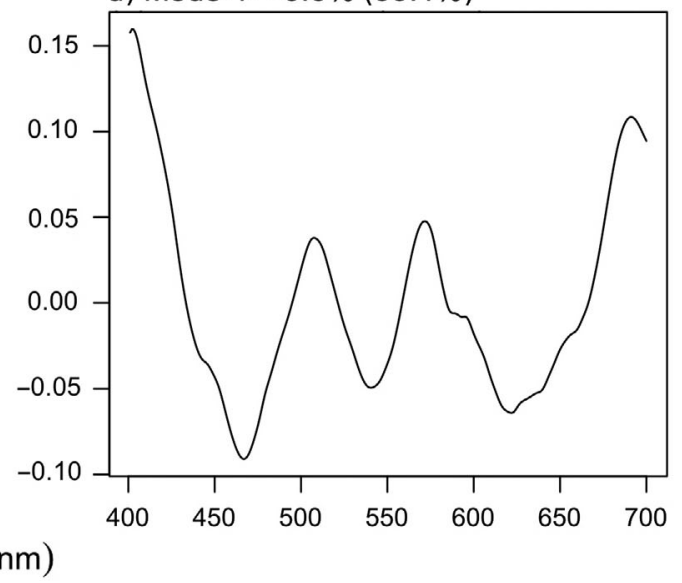

Fig. 10. Loadings, percent variance and cumulative proportion of variance represented (in parentheses) for Modes 1 to 4 of empirical orthogonal function analysis of transmitted spectra for the Winter Weddell Outflow Study (WWOS, Weddell Sea). $\lambda$ : wavelength

We observed a log-linear relationship between integrated chl $a$ and ice thickness (for ice cores less than $1.5 \mathrm{~m}$ length), with equivalent slopes between data sets (Fig. 4), but no significant relationship between chl $a$ and snow depth. Strong inverse relationships between snow cover thickness and ice algal biomass have been reported from both Antarctic and Arctic fast ice habitats in previous studies (e.g. Palmisano et al. 1987, Mundy et al. 2007). We interpret the lack of correlation between snow cover and ice algal biomass in our pack ice dataset to be a result of high snow cover dynamics in the Weddell Sea and East Antarctica, i.e. pack ice snow cover is affected by lateral transport, causing strong redistribution resulting in high temporal variability in winter (Massom et al. 1997, 1998) and most likely also in early spring.

Integrated chl a values reported in this study $(\sim 1$ to $7 \mathrm{mg} \mathrm{m}^{-2}$; Table 2) are much lower than those reported by Campbell et al. (2015) and Mundy et al. (2007) for the Arctic ( 0 to $100 \mathrm{mg} \mathrm{m}^{-2}$ ) and at the lower end of the scale compared with seasonal means from historical circumpolar Antarctic ice core data (0 to $13 \mathrm{mg} \mathrm{m}^{-2}$; Meiners et al. 2012). Low integrated biomass will result in less absorption of transmitted irradiance spectra, thereby influencing the signal-to-noise ratio (e.g. by enhancing the influence of snow cover as demonstrated by Mundy et al. 2007 for the Arctic) and reducing the sensitivity of the derived algorithms. Applying the bio-optical approaches of this study to high sea ice algal biomass habitats, e.g. coastal Antarctic fast ice, may provide even more robust relationships between ice algal chl a concentrations and under-ice irradiance spectra.

\section{Algorithms for estimating chl a}

The best-performing algorithm evaluated was the NDI approach, with NDI models explaining $\sim 60$ to $80 \%$ of observed variation in chl a (Table 3 ). When the NDI ratio identified for the larger data set (SIPEX) was used to fit an algorithm for the smaller 
Table 4. Comparison of normalised difference index (NDI) wavelength ratios and corresponding algorithms for the present study, Campbell et al. (2014) and Mundy et al. (2007) for the Arctic. Note that Mundy et al. used chl a as the predictor and the NDI ratio as the response; equations have been transformed here to match the form used in our study, but $\mathrm{R}^{2}$ values are not comparable. SIPEX: Sea Ice Physics and Ecosystems Experiment; WWOS: Winter Weddell Outflow Study

\begin{tabular}{|c|c|c|c|}
\hline Study/location & NDI ratio & Algorithm & $\mathrm{R}^{2}$ \\
\hline Present study/East Antarctica (SIPEX) & NDI(422:418) & $\ln (\operatorname{chl} a)=-4.27-351 \times \operatorname{NDI}(422: 418)$ & 0.64 \\
\hline Present study/Weddell Sea (WWOS) & NDI(479:468) & $\ln (\operatorname{chl} a)=-0.39-31.7 \times \operatorname{NDI}(479: 468)$ & 0.79 \\
\hline Campbell et al. (2014) & $\operatorname{NDI}(478: 490)$ & $\operatorname{chl} a=15.2-497 \times \mathrm{NDI}(478: 490)$ & 0.81 \\
\hline \multirow[t]{2}{*}{ Mundy et al. (2007) } & NDI(415:400) & chl $a=80.2-588 \times \operatorname{NDI}(415: 400)$ & $0.81^{\mathrm{c}}$ \\
\hline & NDI(485:472) & $\operatorname{chl} a=-8.3+1000 \times \operatorname{NDI}(485: 472)$ & $0.89^{\circ}$ \\
\hline
\end{tabular}

data set (WWOS), the fit was significant $(\mathrm{p}=0.003)$ and explained approximately $40 \%$ of the variability in chl a (Fig. 7a). Mundy et al. (2007) identified the wavelength pairs 415:400 and 485:472 $\mathrm{nm}$ as the best predictors of chl a in Arctic fast ice, with fitted models explaining 81 and $89 \%$ of the variance. Our analyses identified similar NDI ratios of $422: 418$ and 479: $468 \mathrm{~nm}$ as the best predictors for East Antarctica and the Weddell Sea, respectively (see Table 4 for a comparison of wavelength ratios and algorithms). Again using NDI wavelength ratios from a larger data set (Mundy et al. 2007, $\mathrm{n}=47$ ) to fit algorithms for smaller data sets (present study), we found that Mundy et al.'s NDI ratios performed well for the Weddell Sea (explaining 70 and $79 \%$ of the variance) but not as well for East Antarctica (explaining only 45 and $32 \%$ of the variance). This difference may be associated with lower integrated chl a concentrations for East Antarctica (Table 2) as compared with the Weddell Sea and Mundy et al.'s measurements. We suggest that NDIs derived from correlation surfaces perform best among the algorithms we evaluated because they effectively target particular pigments rather than integrating signals across multiple pigments (as summarised in Table 1).

The $E_{\mathrm{d}}(555) / E_{\mathrm{d}}(443)$ ratio, scaled band area and EOFs provided reasonable predictions of chl $a$ at the regional level. Of these 3 methods, EOFs have the advantage of interpretable patterns in EOF loadings, although this would ideally be coupled with measurements of phytoplankton, particulate and coloured dissolved organic matter (CDOM) absorption coefficients for full interpretation (as in Craig et al. 2012). The performance of the scaled band area method $\left(\mathrm{R}^{2}\right.$ values of 0.64 and 0.60 for East Antarctica and the Weddell Sea, respectively) was surprisingly good given that previous applications of this approach (Carrere et al. 2004) were for reflectance spectra. The $E_{\mathrm{d}}(555) / E_{\mathrm{d}}(443)$ ratio also demonstrated reasonable predictive power, particularly for the smaller Weddell Sea dataset $\left(R^{2}=0.67\right)$. We note that Fritsen et al. (2011) successfully used a slight variant of this ratio, $E_{\mathrm{d}}(555) / E_{\mathrm{d}}(442)$, for assessing changes in sea ice algal biomass in the Bellingshausen Sea; these wavelengths correspond with spectral bands tested in the Fritsen et al. study.

\section{What can transmitted spectra tell us about Antarctic pack ice habitats?}

In ice-covered areas, the transmission of solar radiation through sea ice and into the upper ocean is determined by spatial and temporal variations in incident irradiance, ice concentration, snow and ice thickness, and the optical properties of the snow and sea ice. Snow cover strongly affects overall transmission of solar radiation because snow extinction coefficients are more than an order of magnitude larger than those of bare sea ice, and snow albedos can be almost twice as large as those of ice (Grenfell \& Maykut 1977). Other important factors controlling transmission of light through sea ice are its crystalline structure, gas and brine inclusions (which act as scatterers of light; Light et al. 2004) and impurities, for example CDOM (which acts as an absorber in the 280 to $450 \mathrm{~nm}$ range; Belzile et al. 2000). Variability in these features between locations may influence our ability to develop cross-site relationships between transmitted spectra and chl $a$, although the use of particular wavelength ratios is designed to mitigate the effects of such confounding factors.

In contrast to Arctic pack and in particular fast ice, Antarctic pack ice harbours high biomass in surface, interior and bottom communities (Thomas \& Dieckmann 2010, Meiners et al. 2012). Ice algal communities in different depth horizons of the sea ice are exposed to diverse light levels where they use differ- 
ent acclimation strategies that likely strongly affect the transmitted light versus chl a relationship. For example, shade acclimation of ice algae can lead to increases in chl a per cell and increased production of accessory pigments (SooHoo et al. 1987, Alou-Font et al. 2013) that can increase the package effect (i.e. decreased absorption efficiency per chl $a_{i}$ Falkowski \& Raven 2007). Alternatively, high light acclimation can lead to the opposite effect of a decreased package effect due to less chl a per cell. In the context of our study, stations with similar integrated chl a concentrations may therefore have variable optical properties due to different integrated community composition when compared among each other and to Arctic sea ice.

Forward scattering of light in sea ice refers to the process by which surface irradiance is funnelled and focussed towards a smaller area when transmitted from the surface to the bottom layers of sea ice (due to brine and salt inclusions; Light et al. 2004). Surface algal communities in proximity to our collected ice cores may therefore have influenced under-ice irradiance and might not have been properly quantified by our single-core in situ sampling strategy. To quantify this effect, we suggest the sampling of several ice cores at the radiometer site during future studies and also the alternative use of radiance sensors with smaller footprints than cosine sensors. Overall, the comparison of radiometer data and ice core dataand the associated development of algorithms - are impacted by the representativeness of ice core chl $a$ data for the entire footprint sampled by the respective radiometer.

Under-ice phytoplankton biomass may also have affected our measurements. Under-ice phytoplankton biomass was very low during all voyages $\left(<0.2 \mathrm{mg} \mathrm{chl} \mathrm{a} \mathrm{m}^{-3}\right)$ and therefore accounted for a maximum of $3.75 \%$ of the integrated algal biomass above the sensor (Table 2). Future use of moored optical sensors and instrumented vehicles needs to consider potential effects of under-ice algal biomass, which can be high and can also accumulate in aggregates and strands, in particular under Arctic sea ice (Mundy et al. 2011, Arrigo et al. 2012, Boetius et al. 2013), which will affect the applicability of the described optical methods.

\section{CONCLUSIONS}

Our study is the first to compare algorithms for estimating Antarctic sea ice algal biomass using underice irradiance spectra at a regional scale. Our results demonstrate the strong potential to estimate Antarctic ice algal biomass from transmitted under-ice irradiance spectra, in particular using NDIs. Given some degree of regional dependency for our bestperforming method (NDIs), our results suggest that this method may be more appropriate for time series measurements using moored sensors than multiregional mapping efforts (Nicolaus et al. 2013, Campbell et al. 2015). However, explanatory power might be improved through consideration of additional predictive variables (e.g. the vertical distribution of ice algal biomass, the biomass of under-ice phytoplankton or the concentration of non-algal particles).

Nicolaus et al. (2013) found that the seasonal evolution of transmitted solar radiation through landfast sea ice near Barrow, Alaska, USA, exceeded the spatial variability. All 3 of the voyages considered here were carried out early in the season during spring algal biomass buildup. Further work is needed to study interrelationships between ice algal biomass, sea ice particulate and ice algal absorption, and under-ice irradiance throughout the peak and decline of ice algal blooms. For example, senescence of algae is generally accompanied by an increase in chl a degradation products such as pheophytin a (Alou-Font et al. 2013), which shows increased absorption maxima at shorter wavelengths $(410 \mathrm{~nm})$. While the absorption of non-algal particles and coloured dissolved inorganic matter also increases with shorter wavelengths, it might be possible to not only monitor ice algal biomass development but also estimate ice algal health through analysis of underice spectra over time. Further research would also usefully link this work to our understanding of changes in the Antarctic energy budget, as has been done for the Arctic (e.g. Nicolaus et al. 2012).

Acknowledgements. We thank the captains and crews of the RVs 'Polarstern' and 'Aurora Australis' for their continued support during the voyages and E. Allhusen for support of pigment measurements during the WWOS voyage. We also thank A. Constable, R. Trebilco and 3 anonymous reviewers for constructive comments that helped to strengthen this paper. This work was supported by the Australian government's Cooperative Research Centre Program through the Antarctic Climate and Ecosystems Cooperative Research Centre (ACE CRC) and through the Australian Antarctic Science Program (Projects 2767 and 4073).

\section{LITERATURE CITED}

Ackley SF, Lewis MJ, Fritsen CH, Xie H (2008) Internal melting in Antarctic sea ice: development of 'gap layers'. Geophys Res Lett 35:L11503, doi:10.1029/2008GL033644 
Alou-Font E, Mundy CJ, Roy S, Gosselin M, Agustí S (2013) Snow cover affects ice algal pigment composition in the coastal Arctic Ocean during spring. Mar Ecol Prog Ser 474:89-104

Arar EJ, Collins GB (1997) Method 445.0: in vitro determination of chlorophyll $\mathrm{a}$ and pheophytin $\mathrm{a}$ in marine and freshwater algae by fluorescence. In: Methods for the determination of chemical substances in marine and estuarine environmental matrices, 2nd edn. EPA/600/R97/072. National Exposure Research Laboratory, Office of Research and Development, USEPA, Cincinnati, $\mathrm{OH}$, p 445.0-1-445.0.22

> Arrigo KR (2014) Sea ice ecosystems. Annu Rev Mar Sci 6: 439-467

> Arrigo KR, Robinson DH, Sullivan CW (1993) A high resolution study of the platelet ice ecosystem in McMurdo Sound, Antarctica: photosynthetic and bio-optical characteristics of a dense microalgal bloom. Mar Ecol Prog Ser 98:173-185

Arrigo KR, Mock T, Lizotte MP (2010) Primary producers and sea ice. In: Thomas DN, Dieckmann GS (eds) Sea ice. Wiley-Blackwell, Chichester, p 283-326

> Arrigo KR, Perovich DK, Pickart RS, Brown ZW and others (2012) Massive phytoplankton blooms under Arctic sea ice. Science 336:1408

Beeler SooHoo J, Palmisano AC, Kottmeier ST, Lizotte MP, SooHoo SL, Sullivan CW (1987) Spectral light absorption and quantum yield of photosynthesis in sea ice microalgae and a bloom of Phaeocystis pouchetii from McMurdo Sound, Antarctica. Mar Ecol Prog Ser 39:175-189

Belzile C, Johannessen SC, Gosselin M, Demers S, Miller WL (2000) Ultraviolet attenuation by dissolved and particulate constituents of first-year ice during late spring in an Arctic polynya. Limnol Oceanogr 45:1265-1273

Boetius A, Albrecht S, Bakker K, Bienhold C and others (2013) Export of algal biomass from the melting Arctic sea ice. Science 339:1430-1432

> Bricaud A, Claustre H, Ras J, Oubelkheir K (2004) Natural variability of phytoplanktonic absorption in oceanic waters: influence of the size structure of algal populations. J Geophys Res 109:C11010, doi:10.1029/2004 JC002419

Burnham KP, Anderson DR (2002) Model selection and multimodel inference: a practical information-theoretic approach. Springer, New York, NY

> Campbell K, Mundy CJ, Barber D, Gosselin M (2015) Response of remotely estimated ice algae biomass to the environmental conditions during spring melt. J Mar Syst 147:76-84

Carrère V, Spilmont N, Davoult D (2004) Comparison of simple techniques for estimating chlorophyll a concentration in the intertidal zone using high spectral-resolution fieldspectrometer data. Mar Ecol Prog Ser 274:31-40

Craig SE, Jones CT, Li WKW, Lazin G, Horne E, Caverhill C, Cullen JJ (2012) Deriving optical metrics of coastal phytoplankton biomass from ocean colour. Remote Sens Environ 119:72-83

Falkowski PG, Raven JA (2007) Aquatic photosynthesis. Princeton University Press, Princeton, NJ

> Flores H, van Franeker JA, Siegel V, Haraldsson M and others (2012) The association of Antarctic krill Euphausia superba with the under-ice habitat. PLoS ONE 7:e31775

Fritsen CH, Wirthlin ED, Momberg DK, Lewis MJ, Ackley SF (2011) Bio-optical properties of Antarctic pack ice in the early austral spring. Deep-Sea Res II 58:1052-1061
Grenfell TC, Maykut GA (1977) The optical properties of ice and snow in the Arctic basin. J Glaciol 18:445-463

Hawes I, Lund-Hansen LC, Sorrell BK, Nielsen MH, Borzak R, Buss I (2012) Photobiology of sea ice algae during initial spring growth in Kangerlussuaq, West Greenland: insights from imaging variable chlorophyll fluorescence of ice cores. Photosynth Res 112:103-115

Heil P, Allison I, Lytle VI (1996) Seasonal and interannual variations of the oceanic heat flux under a landfast Antarctic sea ice cover. J Geophys Res Oceans 101: 25741-25752

> Holm-Hansen O, Lorenzen CJ, Holmes RW, Strickland JDH (1965) Fluorometric determination of chlorophyll. ICES J Mar Sci 30:3-15

Honda MC, Sasaoka K, Kawakami H, Matsumoto K, Watanabe S, Dickey T (2009) Application of underwater optical data to estimation of primary productivity. Deep-Sea Res I 56:2281-2292

> Legendre L, Gosselin M (1991) In situ spectroradiometric estimation of microalgal biomass in first-year sea ice. Polar Biol 11:113-115

Lemke P (ed) (2009) The expedition of the research vessel 'Polarstern' to the Antarctic in 2006 (ANT-XXIII/7). Reports on Polar and Marine Research, Alfred Wegener Institute for Polar and Marine Research, Bremerhaven

Light B, Maykut GA, Grenfell TC (2004) A temperaturedependent, structural-optical model of first-year sea ice. J Geophys Res 109:C06013, doi:10.1029/2003JC002164

Lizotte MP (2001) The contributions of sea ice algae to Antarctic marine primary production. Am Zool 41:57-73

- Massom RA, Drinkwater MR, Haas C (1997) Winter snow cover on sea ice in the Weddell Sea. J Geophys Res Oceans 102:1101-1117

Massom RA, Lytle VI, Worby AP, Allison I (1998) Winter snow cover variability on East Antarctic sea ice. J Geophys Res Oceans 103:24837-24855

> McDonald S, Koulis T, Ehn J, Campbell K, Gosselin M, Mundy CJ (2015) A functional regression model for predicting optical depth and estimating attenuation coefficients in sea-ice covers near Resolute Passage, Canada. Ann Glaciol 56:147-154

> Meiners KM, Vancoppenolle M, Thanassekos S, Dieckmann GS and others (2012) Chlorophyll $a$ in Antarctic sea ice from historical ice core data. Geophys Res Lett 39: L21602, doi:10.1029/2012GL053478

Mundy CJ, Ehn JK, Barber DG, Michel C (2007) Influence of snow cover and algae on the spectral dependence of transmitted irradiance through Arctic landfast first-year sea ice. J Geophys Res 112:1-10

Mundy CJ, Gosselin M, Ehn JK, Belzile C and others (2011) Characteristics of two distinct high-light acclimated microbial communities during advanced stages of sea ice melt. Polar Biol 34:1869-1886

Nicolaus M, Katlein C, Maslanik J, Hendricks S (2012) Changes in Arctic sea ice result in increasing light transmittance and absorption. Geophys Res Lett 39:L24501, doi:10.1029/2012GL053738

Nicolaus M, Petrich C, Hudson SR, Granskog MA (2013) Variability of light transmission through Arctic land-fast sea ice during spring. Cryosphere 7:977-986

> Palmisano AC, Beeler SooHoo J, Moe RL, Sullivan CW (1987) Sea ice microbial communities. VII. Changes in under-ice spectral irradiance during the development of Antarctic sea ice microalgal communities. Mar Ecol Prog Ser 35:165-173 
Parkinson CL, Cavalieri DJ (2012) Antarctic sea ice variability and trends, 1979-2010. Cryosphere 6:871-880

Perovich DK, Cota GF, Maykut GA, Grenfell TC (1993) Biooptical observations of first-year Arctic sea ice. Geophys Res Lett 20:1059-1062

R Core Team (2015) R: a language and environment for statistical computing. R Foundation for Statistical Computing, Vienna. Available at www.R-project.org/

Saenz BT, Arrigo KR (2014) Annual primary production in Antarctic sea ice during 2005-2006 from a sea ice state estimate. J Geophys Res Oceans 119:3645-3678

Taylor BB, Taylor MH, Dinter T, Bracher A (2013) Estimation of relative phycoerythrin concentrations from hyperspectral underwater radiance measurements - a statistical approach. J Geophys Res Oceans 118:2948-2960

Thomas DN, Dieckmann GS (eds) (2010) Sea ice, 2nd edn. Wiley-Blackwell, Chichester

van Leeuwe MA, van Sikkelerus B, Gieskes WWC, Stefels J (2005) Taxon-specific differences in photoacclimation to

Editorial responsibility: Steven Lohrenz,

New Bedford, Massachusetts, USA fluctuating irradiance in an Antarctic diatom and a green flagellate. Mar Ecol Prog Ser 288:9-19

Vancoppenolle M, Goosse $\mathrm{H}$, de Montety A, Fichefet T, Tremblay B, Tison JL (2010) Modeling brine and nutrient dynamics in Antarctic sea ice: the case of dissolved silica. J Geophys Res Oceans 115:C02005, doi:10.1029/2009JC 005369

- Vancoppenolle M, Meiners KM, Michel C, Bopp L and others (2013) Role of sea ice in global biogeochemical cycles: emerging views and challenges. Quat Sci Rev 79:207-230

Worby AP, Allison I (1999) A technique for making shipbased observations of Antarctic sea ice thickness and characteristics. Part I: observational technique and results. Res Rep No. 14, Antarctic Cooperative Research Centre, Hobart

Worby AP, Steer A, Lieser JL, Heil P and others (2011) Regional-scale sea-ice and snow thickness distributions from in situ and satellite measurements over East Antarctica during SIPEX 2007. Deep-Sea Res II 58:1125-1136

Submitted: December 16, 2014; Accepted: June 15, 2015

Proofs received from author(s): September 22, 2015 